\title{
PROTOTYPE ALAT PEMBUKA PINTU OTOMATIS MENGGUNAKAN PENDETEKSI MASKER DENGAN ARDUINO
}

\author{
Sukri Adrianto ${ }^{1}$, Nurhadi ${ }^{2}$, Masrizal $^{3}$ M. Teddy Syahputra ${ }^{4}$, Yuhardi $^{5}$ \\ 1,2,3,, Sekolah Tinggi Manajemen Informatika dan Komputer (STMIK) Dumai \\ 5, Sekolah Tinggi Ilmu Ekonomi Tuah Negeri Dumai \\ Jl. Utama Karya Bukit Batrem Dumai-Riau Kode Pos 28811 \\ Jl. Bintan No 48 Dumai Kota - Riau Kode Pos 28826 \\ e-mail :sukriadrianto@gmail.com¹, flinkdumai@gmail.com²,masrizal100620@gmail.com³ \\ syahputrateddy7@gmail.com ${ }^{4}$,yudimanafstie@ gmail.com ${ }^{5}$
}

\begin{abstract}
ABSTRAK
Saat pandemi covid-19 masih banyak masyarakat yang tidak menggunakan masker di tempat publik. Oleh karena itu, tujuan penelitian ini adalah membuat prototype alat untuk mengontrol pintu otomatis pada area/ruangan wajib masker, manfaat alat ini untuk membantu pencegahan penyebaran covid-19 dari masyarakat yang tidak menggunakan masker. Dasar dari penelitian ini adalah Machine learning yang memiliki kemampuan untuk memperoleh data yang ada dengan perintah ia sendiri, dan dapat mempelajari data yang ada dan data yang ia peroleh, sehingga bisa melakukan tugas yang diperintahkan. Prototype ini menggunakan bahasa pemrograman python untuk membuat machine learning, Arduino sebagai microcontroller dan camera sebagai pendeteksi penggunaan masker, sedangkan pintu otomatisnya akan terbuka dengan menggunakan motor servo. Keluaran dari penelitian ini berupa prototype alat yang akan membuka pintu secara otomatis, tripod untuk dudukan camera, miniatur pintu otomatis, serta tempat arduino uno.
\end{abstract}

Kata kunci : Arduino uno, Camera, Machine learning, masker, Python

\begin{abstract}
During the COVID-19 pandemic, many people did not wear masks in public places. Therefore, the purpose of this research is to make a prototype of a tool to control automatic doors in areas/rooms that are mandatory for masks, the benefits of this tool are to help prevent the spread of covid-19 from people who do not use masks. The basis of this research is machine learning which has the ability to obtain existing data by its own command, and can study existing data and the data it obtains, so that it can perform the tasks ordered. This prototype uses the python programming language to make machine learning, Arduino as a microcontroller and a camera as a detector for the use of masks, while the automatic door will open using a servo motor. The output of this research is a prototype tool that will open the door automatically, a tripod for a camera mount, a miniature automatic door, and an Arduino Uno holder.
\end{abstract}

Keywords : Arduino uno, Camera, Machine learning, mask, Python

\section{PENDAHULUAN}

Wabah Covid-19 menjadi pandemi global setelah diumumkan oleh World Health Organization $(\mathrm{WHO})$ atau Organisasi Kesehatan Dunia dan dengan penyebarannya yang begitu cepat membuat Covid-19 menjadi topik utama di penjuru dunia. Tidak terkecuali di Indonesia karena jumlah masyarakat yang terinfeksi virus Covid-19 atau Corona ini mengalami peningkatan hari demi hari. Kasus virus ini 


\section{IN F ORM A I I A}

\section{Jurnal Informatika, Manajemen dan Komputer, Vol. 13, No. 2, Desember 2021}

elSSN : 2580-3042

pISSN : 1979-0694

dimulai dengan pneumonia atau radang paru-paru misterius pada Desember 2019 yang lalu. Kasus ini diduga berkaitan dengan pasar hewan huanan di Wuhan yang menjual berbagai jenis daging binatang, termasuk yang tidak biasa dikomsumsi, misalnya ular, kelelawar, dan berbagai jenis tikus.

Penyebaran virus ini paling banyak dilakukan melalui sentuhan terhadap benda disekitar yang tanpa kita sadari. Contohnya adalah ketika kita hendak memasuki suatu gedung atau ruangan, kita menyentuh ganggang pintu untuk membuka pintu tersebut, dan virus tersebut bisa dengan mudah menyebar dengan sentuhan tersebut. Oleh karena itu cara untuk menghindari terkena virus ini adalah meminimalisir sentuhan dan juga menghindari kerumunan.

Pemerintah menerapkan program 3M untuk pencegahan penyebaran virus ini, yaitu mencuci tangan, menjaga jarak, dan menggunakan masker. Maka dari itu dibuatlah prototype alat pintu otomatis yang akan terbuka jika orang yang mau masuk ke dalam ruangan itu harus menggunakan masker. Sehingga bisa menghindari kontak langsung dengan ganggang pintu yang pasti banyak disentuh orang lain.

Tujuan dari penelitian ini adalah untuk Menganalisa komponen yang akan digunakan untuk membuat alat pembuka pintu otomatis deteksi masker, seperti : machine learning, arduino, motor servo, Light Emitting Diode (LED), DLL. Dan Menciptakan suatu prototype alat yang akan mengingatkan seseorang untuk selalu menggunakan masker disaat pandemi.

\section{a. Sistem}

Menurut (Indrajani, 2015) di dalam jurnalnya (Sari et al. 2017), Sistem adalah sekelompok elemen yang saling berhubungan atau berinteraksi hingga membentuk satu persatuan. Konsep umum sistem adalah sekelompok komponen yang saling berhubungan, bekerja sama untuk mencapai tujuan bersama dengan menerima input serta menghasilkan output dalam proses transformasi yang teratur.

\section{b. Karakteristik sistem}

Sebuah sistem mempunyai karakteristik atau sifat-sifat tertentu yang mencirikan bahwa hal tersebut bisa dikatakan sebagai suatu sistem.
Adapun karakteristik yang dimaksud adalah sebagai berikut :

1. Komponen Sistem (Components),

Suatu sistem terdiri dari sejumlah komponen yang saling berinteraksi, yang bekerja sama membentuk satu kesatuan. Komponenkomponen sistem tersebut dapat berupa suatu bentuk subsistem. Setiap subsistem memiliki sifat-sifat sistem yang menjalankan suatu fungsi tertentu dan mempengaruhi proses sistem secara keseluruhan. Suatu sistem dapat mempunyai sistem yang lebih besar yang disebut dengan supra sistem.

2. Batasan Sistem (Boundary),

Ruang lingkup sistem merupakan daerah yang membatasi antara sistem dengan sistem lainnya atau sistem dengan lingkungan luarnya. Batasan sistem ini memungkinkan suatu sistem dipandang sebagai satu kesatuan yang tidak dapat dipisah-pisahkan.

3. Lingkungan Luar Sistem (Environment), Merupakan lingkungan sistem atau batasan sistem yang mempengaruhi operasi sistem yang dapat bersifat menguntungkan dan dapat juga merugikan sistem tersebut.

4. Penghubung Sistem (Interface),

Media yang menghubungkan sistem dengan subsistem yang lain disebut dengan penghubung sistem atau interface. Penghubung ini memungkinkan sumbersumber daya mengalir dari satu subsistem ke subsistem lain. Keluaran suatu subsistem akan menjadi masukan untuk subsistem yang lain dengan melewati penghubung. Dengan demikian terjadi suatu integrasi sistem yang membentuk satu kesatuan.

5. Masukan Sistem (Input),

Energi yang dimasukkan ke dalam sistem disebut masukan sistem, yang dapat berupa pemeliharaan (maintenance input) dan sinyal (signal input).

6. Keluaran sistem(Output),

Hasil dari energi yang diolah dan diklasifikasikan menjadi keluaran yang berguna. Contohnya, informasi yang berguna dalam pengambilan keputusan.

7. Pengolahan Sistem (Proccess), 
IN F ORM A I K

Jurnal Informatika, Manajemen dan Komputer, Vol. 13, No. 2, Desember 2021

eISSN : 2580-3042

pISSN : 1979-0694

Suatu sistem dapat mempunyai suatu proses yang akan mengubah masukan menjadi keluaran. Contohnya, pengolahan data transaksi menjadi sebuah laporan yang dibutuhkan manajemen.

8. Sasaran Sistem (Objektive).

Suatu sistem memiliki tujuan dan sasaran yang pasti dan bersifat deterministik. Kalau suatu sistem tidak memiliki sasaran, maka operasi sistem tidak ada gunaya. Suatu sistem dikatakan berhasil bila mengenai sasaran atau tujuan yang telah direncanakan.

\section{c. Flowchart}

Dalam jurnal (Santoso and Nurmalina 2017), Flowchart adalah representasi secara simbolik dari suatu algoritma atau prosedur untuk menyelesaikan suatu masalah, dengan menggunakan flowchart akan memudahkan pengguna melakukan pengecekan bagian-bagian yang terlupakan dalam analisis masalah, disamping itu flowchart juga berguna sebagai fasilitas untuk berkomunikasi antara pemrogram yang bekerja dalam tim suatu proyek. Flowchart membantu memahami urutan-urutan logika yang rumit dan panjang. Flowchart membantu mengkomunikasikan jalannya program ke orang lain (bukan pemrogram) akan lebih mudah.

\section{d. Microkontroler}

Menurut (Wahyudin, 2007) didalam jurnalnya (Adrianto 2019) komputer yang seluruh atau sebagian besar elemennya dikemas dalam satu chip IC, sehingga sering disebut single chip microcomputer. Lebih lanjut, mikrokontroler merupakan sistem komputer yang mempunyai satu atau beberapa tugas yang sangat spesifik, berbeda dengan PC yang memiliki beragam fungsi.Perbedaan lainnya adalah perbandingan RAM dan ROM yang sangat berbeda antara komputer dengan mikrokontroler. Dalam mikrokontroler, ROM jauh lebih besar disbanding RAM, sedangkan dalam komputer atau PC RAM jauh lebih besar disbanding ROM.

\section{e. Arduino uno}

Menurut (Djuandi 2011), Arduino dikatakan sebagai sebuah platform dari physical computing yang bersifat open source. Arduino tidak hanya sekedar sebuah alat pengembangan, tetapi ia adalah kombinasi dari hardware, bahasa pemrograman dan Integrated Development Environment (IDE) yang canggih. IDE adalah sebuah software yang sangat berperan untuk menulis program, meng-compile menjadi kode biner dan meng-upload ke dalam memory microcontroller. Ada banyak projek dan alat-alat dikembangkan oleh akademisi dan profesional dengan menggunakan arduino, selain itu juga ada banyak modul-modul pendukung (sensor, tampilan, penggerak dan sebagainya) yang dibuat oleh pihak lain untuk bisa disambungkan dengan arduino.

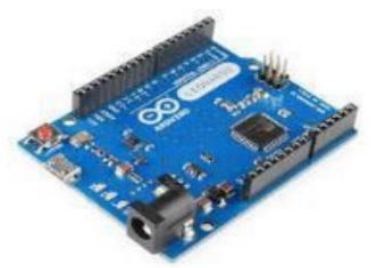

Gambar 1. Arduino uno

\section{f. Soket USB}

Dalam jurnal (Ihsanto and Hidayat 2014), Soket USB adalah soket untuk kabel USB yang disambungkan ke komputer atau laptop yang berfungsi untuk mengirimkan program ke arduino dan juga sebagai port komunikasi serial. Sambungan dari komputer ke board Arduino menggunakan USB, bukan serial atau parallel port, sehingga akan mudah menghubungkan Arduino ke PC atau laptop yang tidak memiliki serial/parallel port. Arduino Uno menggunakan chip AVR Atmega 328 yang memiliki fasilitas PWM, komunikasi serial, ADC, timer, interupt, SPI dan 12C. Sehingga Arduino bisa digabungkan bersama modul atau alat lain dengan protokol yang berbeda-beda.

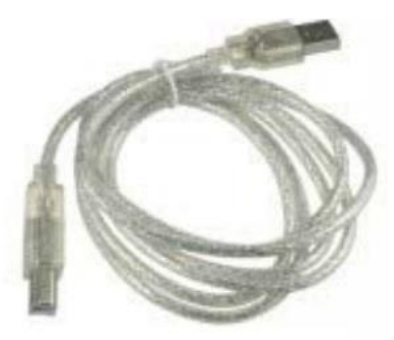

Gambar 2. Soket USB 
IN F ORM A I K A

Jurnal Informatika, Manajemen dan Komputer, Vol. 13, No. 2, Desember 2021

eISSN : 2580-3042

pISSN : 1979-0694

\section{g. Software Arduino IDE}

Dalam jurnal (Slamet Winardi \& dkk 2020:10), Kepanjangan dari IDE adalah Integrated Developtment Environment, atau bahasa Indonesia-nya adalah lingkungan pengembangan yang terintegrasi yang digunakan untuk penulisan suatu pemrograman. Dikenal sebagai environment karena dengan software inilah pemrograman untuk arduino dilakukan dengan membuat fungsi-fungsi melalui sintaks pemrograman yang akan di upload dalam chip arduino. Dalam membuat program untuk arduino digunakan bahasa pemrograman tersendiri yang menyerupai bahasa $\mathrm{C}$ yang sejatinya dibuat dari bahasa pemrograman Java dan merupakan turunan dari software processing. Bahasa pemrograman arduino atau yang disebut dengan sketch sudah dilakukan modifikasi dari software processing untuk memudahkan pengguna dalam membuat sebuah program dari bahasa aslinya. Dalam sebuah board arduino, IC mikrokontroler ATmega328 telah diberi program bootlader yang mempunyai fungsi sebagai penghubung antara computer dengan board arduino.

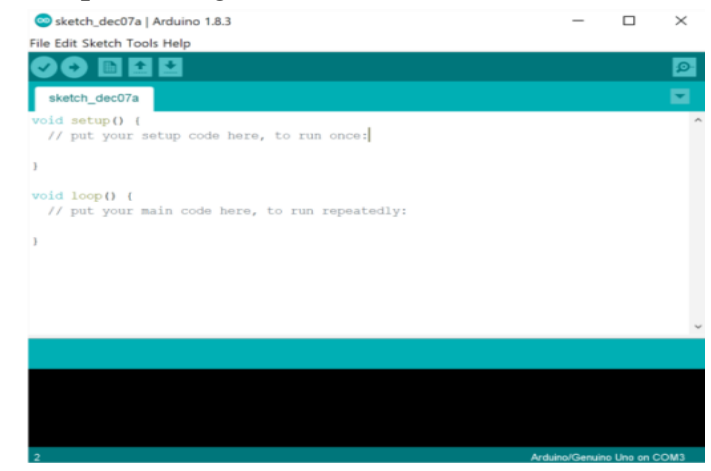

Gambar 3.Software arduino ide

\section{h. Motor servo}

Dalam buku (Hilal and Manan 2015), Motor servo adalah sebuah motor dengan sistem closed feedback di mana posisi dari motor akan diinformasikan kembali ke rangkaian kontrol yang ada di dalam motor servo. Motor ini terdiri dari sebuah motor, serangkaian gear, potensiometer dan rangkaian kontrol. Motor ini terdiri dari sebuah motor DC, serangkaian gear, potensiometer dan rangkaian kontrol. Potensiometer berfungsi untuk menentukan batas sudut dari putaran servo. Sedangkan sudut dari sumbu motor servo diatur berdasarkan lebar pulsa yang dikirim melalui kaki sinyal dari kabel motor. Dengan pulsa $1.5 \mathrm{mS}$ pada periode selebar $2 \mathrm{mS}$ maka sudut dari sumbu motor akan berada pada posisi tengah. Semakin lebar pulsa OFF maka akan semakin besar gerakan sumbu ke arah jarum jam dan semakin kecil pulsa OFF maka akan semakin besar gerakan sumbu ke arah yang berlawanan dengan jarum jam.

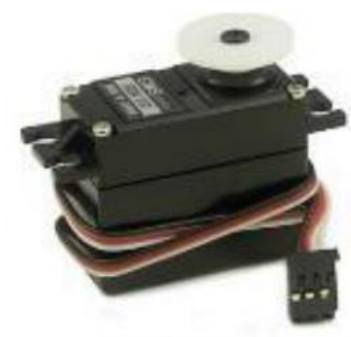

Gambar 4. Motor servo

\section{i. LED}

Dalam jurnal (Faridha and Saputra 2016), $L E D$ atau singkatan dari Light Emitting Diode adalah salah satu komponen elektronik yang tidak asing lagi di kehidupan saat ini. LED banyak dipakai, seperti untuk penggunaan lampu penerangan, rambu-rambu lalu lintas, lampu indikator peralatan elektronik hingga ke industri. $L E D$ ini banyak digunakan karena komsumsi daya yang dibutuhkan tidak terlalu besar.

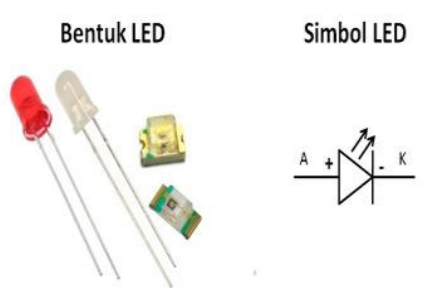

Gambar 5. Bentuk dan simbol LED

\section{j. Buzzer}

Dalam jurnal (Fani et al. 2020), Buzzer adalah sebuah elektronika yang berfungsi mengubah getaran listrik menjadi getaran suara. Pada dasarnya cara kerja buzzer hampir sama dengan loud speaker, Buzzer terdiri dari kumparan yang terpasang pada diafragma. Buzzer biasa digunakan sebagai indikator bahwa 
IN F O R M A T I A

Jurnal Informatika, Manajemen dan Komputer, Vol. 13, No. 2, Desember 2021

eISSN : 2580-3042

pISSN : 1979-0694

proses telah selesai atau terjadi suatu kesalahan pada sebuah alat.

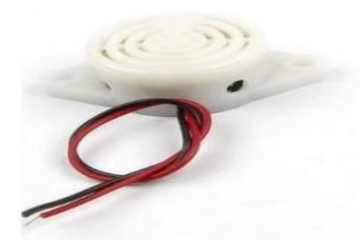

Gambar 6. Buzzer

\section{k. Machine learning}

Menurut (Dr. Purba daru kusuma, 2020:1), Machine learning adalah aplikasi atau bagian dari kecerdasan buatan yang membuat sistem memiliki kemampuan belajar secara otomatis dan meningkatkan kemampuannya berdasarkan pengalaman tanpa diprogram secara eksplisit. Dalam hal ini, program komputer tidak ditulis secara statis. Fokus machine learning terdapat pada pengembangan program komputer yang dapat mengakses data dan belajar dari data tersebut.

\section{Bahasa pemrograman python}

Menurut (Abdul Kadir, 2019:27), Python merupakan bahasa pemrograman serbaguna yang diciptakan oleh Guido van Rossum pada tahun 1991. Bahasa ini dirancang agar kode mudah untuk dibaca oleh orang. Sebagai perwujudannya, penggunaan spasi untuk mengatur identitasi kode sangat signifikan. Dengan demikian, penambahan spasi pada kode tidak dapat dilakukan sembarangan. Seperti halnya $\mathrm{C}++$, Python bersifat portabel dalam kode sumber. Kode sumber dapat digunakan pada berbagai platform seperti Windows, Mac OS, dan Linux.

Menurut (Jubile Enterprise, 2019:1), Python secara umum berbentuk pemrograman berorientasi objek, pemrograman imperatif, dan pemrograman fungsional. Istilah lainnya, bahasa pemrograman multi-paradigma. Python dapat digunakan untuk berbagai keperluan pengembangan perangkat lunak dan dapat berjalan di berbagai platform sistem operasi.
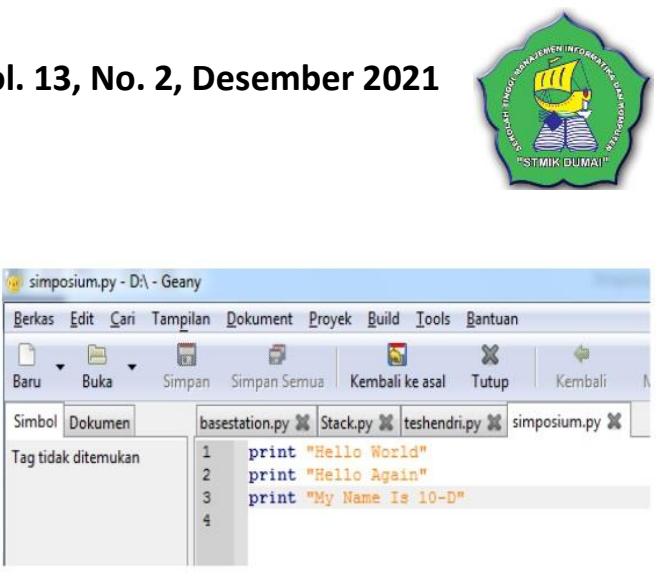

Gambar 7. Contoh program python

\section{m. Webcam}

Menurut (Rohpandi, Permana, and Muldiana 2013), Web camera (webcam) adalah sebuah alat yang terhubung ke komputer berfungsi untuk mengambil citra dari lensa teleskoptik yang terdapat pada alat tersebut. Citra yang diambil ini kemudian dikirimkan ke komputer melalui kabel USB (Universal Serial $B U S$ ) atau kabel serial dengan kecepatan realtime (kurang lebih 15 frame per detik). Web camera saat ini dipergunakan secara luas pada aplikasi online video conference, pemantauan, sebagai kamera digital, dan banyak lagi. Resolusi (ketajaman) maksimum citra hasil dari web camera adalah 640 x 480 pixel. Sebuah web camera yang sederhana terdiri dari sebuah lensa standar, dipasang di sebuah papan sirkuit untuk menangkap sinyal gambar; casing (cover), termasuk casing depan dan casing samping untuk menutupi lensa standar dan memiliki sebuah lubang lensa di casing depan yang berguna untuk memasukkan gambar, kabel support, yang dibuat dari bahan yang fleksibel, salah satu ujungnya dihubungkan dengan papan sirkuit dan ujung satu lagi memiliki connector, kabel ini dikontrol untuk menyesuaikan ketinggian, arah dan sudut pandang web camera. Webcam yang digunakan dalam sistem ini berfungsi untuk menangkap gambar yang akan dilihat oleh pemakai, dan juga sebagai gambar yang akan dipindai oleh perangkat lunak untuk mendeteksi adanya gerakan. 
IN F ORM A T I R

Jurnal Informatika, Manajemen dan Komputer, Vol. 13, No. 2, Desember 2021

eISSN : 2580-3042

pISSN : 1979-0694

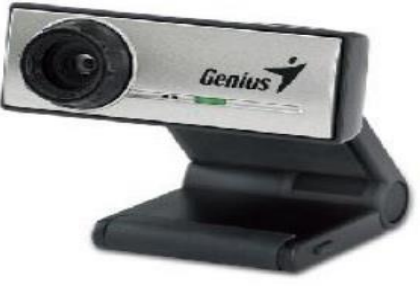

Gambar 8. Webcam

\section{METODOLOGI PENELITIAN}

Metode penelitan yang digunakan dalam penelitian ini adalah sebagai berikut :

1. Identifikasi masalah

Mengidentifikasi masalah merupakan langkah pertama yang dilakukan dalam tahap analisis sistem. Masalah (problem) dapat didefinisikan sebagai suatu pertanyaan yang diinginkan untuk dicapai. Identifikasi masalah dimulai dari melihat dan menyimpulkan masalah-masalah yang terjadi. Dan pada masalah yang saya bahas adalah pintu otomatis yang akan terbuka jika seseorang sedang menggunakan masker, yang akan sangat berguna karena saat ini kita sedang mengalami pandemi dan wajib menggunakan masker jika berpergian.

2. Studi Literatur

Untuk mengetahui solusi, cara atau metode yang akan digunakan dalam pemecahan masalah yang ada pada studi literatur meliputi studi pustaka yang bersumber dari buku,jurnal, dan juga internet untuk mengetahui bagaimana cara untuk membuat alat pembuka pintu otomatis menggunakan deteksi masker ini.

3. Pengumpulan alat dan bahan

Dalam pembuatan pintu otomatis deteksi masker ini menggunakan mikrokontroller arduino uno, motor servo, led dan beberapa komponen pendukung lainnya.

4. Perancangan alat

Membuat perancangan alat yang bersifat sementara dan berfokus pada penyajian (contoh membuat input dan format output). Dan bagaimana tampilan alat yang akan dibangun tersebut.

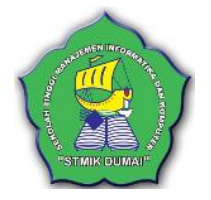

5. Pembuatan alat

Tahapan dimana alat akan dirangkai dan bahan yang sudah disiapkan sesuai dengan logika yang telah disiapkan untuk membuat pintu otomatis deteksi masker ini.

6. Pengujian Alat

Setelah selesai dengan pembuatan alat, maka diperlukan pengujian terlebih dahulu, untuk mengecek kembali alat yang telah dibuat apakah berjalan sesuai dengan yang telah direncanakan dan sesuai dengan tujuan penelitian.

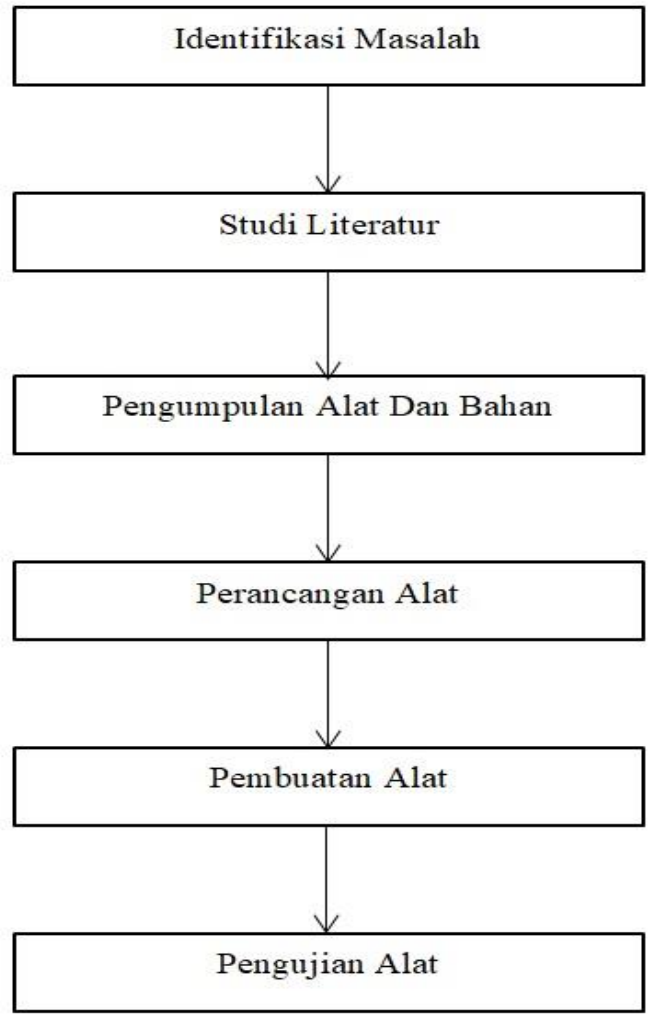

Gambar 9. Kerangka kerja

\section{HASIL DAN PEMBAHASAN}

ArduinoIDE merupakan perangkat lunak yang berasal dari arduino sendiri yang digunakan untuk pemrograman pada arduino. Agar kode program dapat di upload untuk dijalankan pada arduino uno yang digunakan pada menu tools board. Untuk menjalankan arduino uno dan IDE, hubungkan arduino uno dengan komputer menggunakan USB. Setelah IDE arduino uno terhubung dengan komputer, arduino uno telah dapat digunakan untuk melakukan penulisan 
IN F O R M A I I A

Jurnal Informatika, Manajemen dan Komputer, Vol. 13, No. 2, Desember 2021

eISSN : 2580-3042

pISSN : 1979-0694

kode program dan diunggah ke mikrokontroller untuk dijalankan.

\section{a. Machine learning menggunakan python}

Machine learning merupakan aplikasi komputer dan algoritma matematika yang diadopsi dengan cara pembelajaran yang berasal dari data dan menghasilkan prediksi di masa yang akan datang. Adapun proses pembelajaran yang dimaksud adalah suatu usaha dalam memperoleh kecerdasan yang melalui dua tahap, antara lain tahap latihan (training) dan pengujian (testing).

\section{b. Input koding ke arduino}

menginput atau memasukkan koding dari aplikasi ArduinoIDE ke board arduino. Hubungkan kabel USB ke port yang ada di arduino, setelah itu hubungkan juga kabel USB ke port laptop atau PC yang sudah terinstall ArduinoIDE.

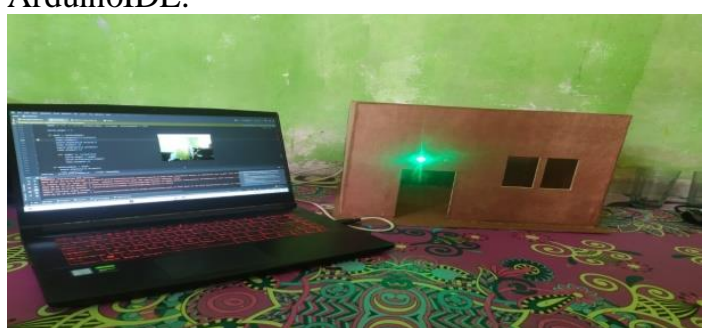

Gambar 10. Kabel port USB terhubung ke laptop

\section{c. Koding python ke arduino}

input koding dari ArduinoIDE ke arduino kita hanya memasukkan library yang akan dibutuhkan untuh bisa digunakan pada bahasa pemrograman pyhon ini. Dan pada bahasa pemrograman python kita mengendalikan arduino tersebut dengan cara memasukkan koding yang dibutuhkan untuk mengendalikan hardware yang telah tersedia.

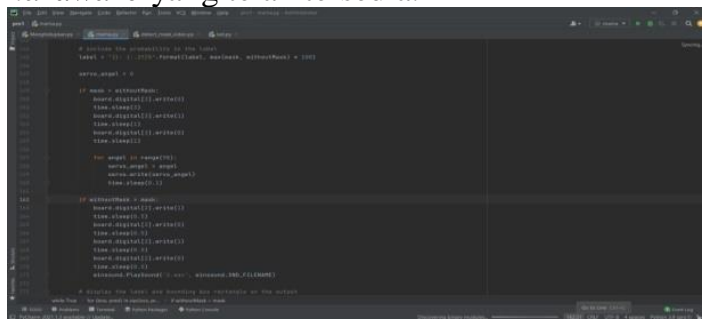

Gambar 11. Coding python ke arduino

\section{d. Perangkat keras yang digunakan}

Perangkat keras atau hardware merupakan perangkat penyusun yang dapat dilihat secara fisik, perangkat keras ini merupakan komponen yang sangat penting dalam perangkaian alat yang akan dibuat. Komponen perangkat keras yang dibutuhkan dalam pembuatan sistem, yang

kemudian seluruh komponen alat dirangkai menjadi satu kesatuan dan membentuk sebuah sistem yang utuh.

Komponen perangkat keras yang dibutuhkan adalah :
a. Perangkat komputer
b. Arduino Uno
c. Motor servo
d. Kabel USB Arduino Uno
e. LED
f. Kabel jumper
g. Buzzer
h. Webcam
i. Miniatur rumah dan pintu

\section{e. Rangkaian komponen}

Komponen yang telah dirangkai secara keseluruhan kemudian diletakkan didalam miniatur rumah supaya terlihat lebih rapi, miniatur rumah tersebut diberi lubang untuk jalur kabel USB dari port arduino ke laptop.

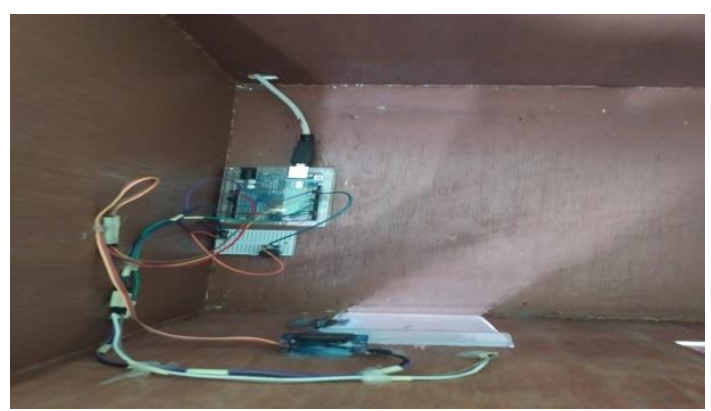

Gambar 12. Susunan rangkaian pada alat

Dibagian luar diletakkan tripod dan webcam sebagai yang mendeteksi penggunaan masker. Dan juga laptop yang berfungsi sebagai proses machine learning.

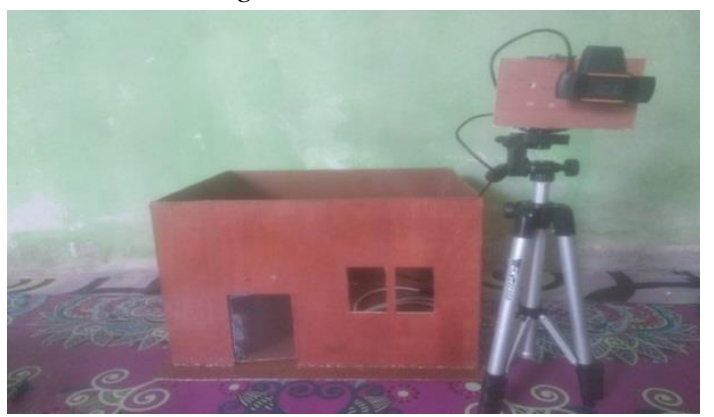

Gambar 13. Bagian luar 
INFORMA TIK

Jurnal Informatika, Manajemen dan Komputer, Vol. 13, No. 2, Desember 2021

eISSN : 2580-3042

pISSN : 1979-0694

LED hijau di bagian depan miniatur rumah berfungsi sebagai indikator pemberitahuan bahwa sistem sedang dalam keadaan aktif lalu LED akan berkedip sekali dan pintu terbuka jika kamera mendeteksi orang menggunakan maser, dan LED merah sebagai indicator pemberitahuan bahwa sistem mendeteksi seseorang yang tidak menggunakan masker dan nanti akan memberi peringatan berupa pesan suara lewat speaker.

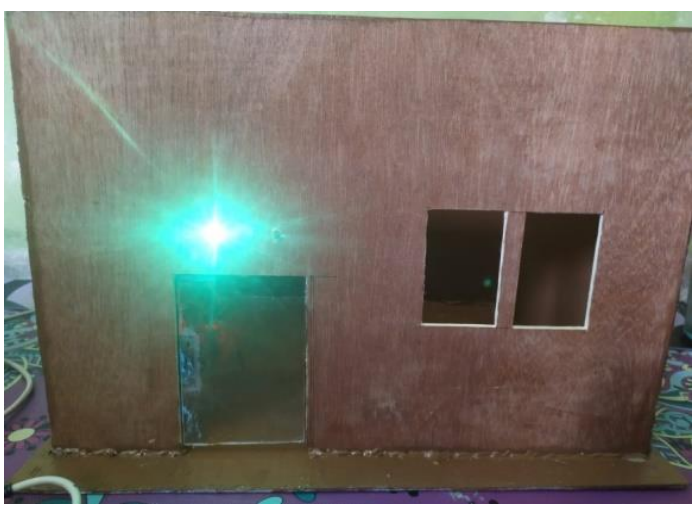

Gambar 14. Alat keadaan aktif

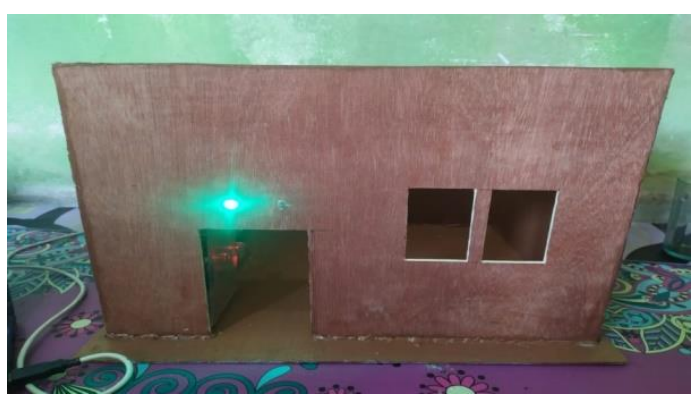

Gambar 15. Pintu terbuka

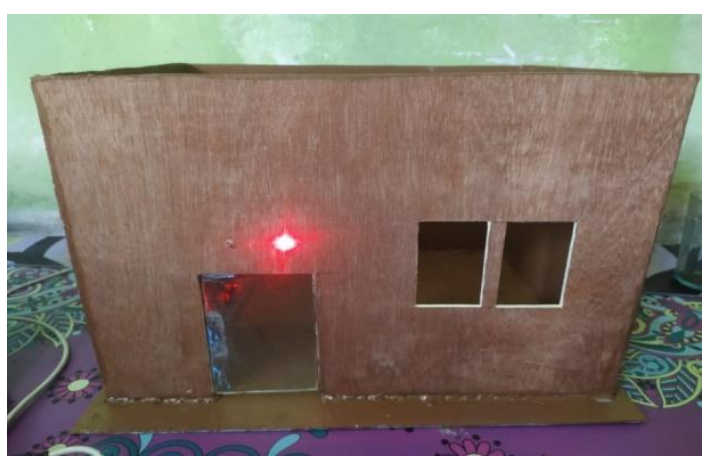

Gambar 16. Alat mendeteksi tidak memakai masker 
INFORM A IK

Jurnal Informatika, Manajemen dan Komputer, Vol. 13, No. 2, Desember 2021

elSSN : 2580-3042

pISSN : 1979-0694

Ihsanto, Eko, and Sadri Hidayat. 2014. "RANCANG BANGUN SISTEM PENGUKURAN Ph METER DENGAN MENGGUNAKAN MIKROKONTROLLER ARDUINO UNO.” Jurnal Teknologi Elektro 5(3).

Jubilee Enterprise. (2019). Python Untuk Programmer Pemula. Jakarta

Rohpandi, Dani, Soleh Permana, and Fahrurizal Muldiana. 2013. "Sistem Pemantauan Ruangan Dengan Webcam Menggunakan Metode Motion Detection." Jurnal VOI (Voice Of Informatics) 1.

Santoso, Santoso, and Radna Nurmalina. 2017. "Perencanaan Dan Pengembangan Aplikasi Absensi Mahasiswa Menggunakan Smart Card Guna Pengembangan Kampus Cerdas (Studi Kasus Politeknik Negeri Tanah Laut)." Jurnal Integrasi 9(1): 84-91.

Slamet Winardi, Arief Budijanto, Kunto Eko Susilo, Tresna Maulana Fahrudin. (2020). Desain Mobile Robot Dengan Kendali Smart Phone Android. Surabaya

Sari, Uci Yulia et al. 2017. "Sistem Pengolahan Data Produksi Dan Penjualan Es Balok Pada Upt Ppi Kota Dumai." Jurnal Informatika, Manajemen dan Komputer 9(2): 51-59.

Tata sutabri. (2012). Analisis Sistem Informasi. Yogyakarta 